\title{
Nitrogen stable isotopes indicate differences in nitrogen cycling between two contrasting Jamaican montane forests
}

5 Francis Q. Brearley ${ }^{1,2}$

${ }^{1}$ Department of Botany, Trinity College, University of Dublin, Dublin 2, Ireland

2 School of Science and the Environment, Manchester Metropolitan University, Chester Street, Manchester, M15GD, UK (f.q.brearley@mmu.ac.uk)

10 Abstract

Background and Aims The aim of this study is to enhance our knowledge of nitrogen (N) cycling and $\mathrm{N}$ acquisition in tropical montane forests through analysis of stable $\mathrm{N}$ isotopes $\left(\delta^{15} \mathrm{~N}\right)$.

Methods Leaves from eight common tree species, leaf litter, soils from three depths and roots were sampled from two contrasting montane forest types in Jamaica (mull ridge and mor ridge) and were analysed for $\delta^{15} \mathrm{~N}$.

Results All foliar $\delta^{15} \mathrm{~N}$ values were negative and varied among the tree species but were significantly more negative in the mor ridge forest (by about $2 \%$ ). $\delta^{15} \mathrm{~N}$ of soils and roots were also more negative in mor ridge forests by about $3 \%$. Foliar $\delta^{15} \mathrm{~N}$ values were closer to that of soil ammonium than soil nitrate suggesting that trees in these forests may have a preference for ammonium; this may explain the high losses of nitrate from similar tropical montane forests. There was no correlation between the rankings of foliar $\delta^{15} \mathrm{~N}$ in the two forest types suggesting a changing uptake ratio of different $\mathrm{N}$ forms between forest types.

Conclusions These results indicate that $\mathrm{N}$ is found at low concentrations in this ecosystem and that there is a tighter $\mathrm{N}$ cycle in the mor ridge forest, confirmed by reduced nitrogen availability and lower rates of nitrification. Overall, soil or root $\delta^{15} \mathrm{~N}$ values are more useful in assessing ecosystem $\mathrm{N}$ cycling patterns as different tree species showed differences in foliar $\delta^{15} \mathrm{~N}$ between the two forest types.

30 Running head Nitrogen isotopes in tropical montane forests

Key words Jamaica; tropical montane forest; nitrogen cycling; nitrogen isotopes; soils 


\section{Introduction}

35 Understanding ecosystem nutrient cycling is important as soil nutrient availability has a strong effect on plant and microbial growth, performance and community composition which, in turn, will affect ecosystem productivity and other biogeochemical processes. Understanding nutrient cycling is also important from the point of view of community ecology, as variation in nutrients in both space and time may lead to species co-existence

40 through partitioning of various aspects of this essential resource (e.g. McKane et al. 2002). The nature of nutrient limitation in tropical rain forests is still being debated, but a simple interpretation of current evidence suggests that lowland forests on old and highly weathered soils are more limited by phosphorus whereas montane forests are more limited by the supply of nitrogen $(\mathrm{N})$ due to slower $\mathrm{N}$ mineralisation rates in the cooler climates (Tanner et al. 1998). Furthermore, with increased $\mathrm{N}$ deposition to tropical forests which is predicted to increase in the future, we need to improve our understanding of tropical forest N cycling (Ortiz-Zayas et al. 2006; Phoenix et al. 2007; Hietz et al. 2011)

The $\mathrm{N}$ cycle is complex and below-ground controls on $\mathrm{N}$ cycling can be difficult to study due to the hidden nature of the soil environment. Stable isotopes are becoming increasingly important in studies of $\mathrm{N}$ cycling as they provide a time-integrated measure of ecosystem processes (reviewed in Högberg 1997; Robinson 2001; Evans 2007; Makarov 2009). For example, they can identify sources, infer processes, estimate rates, determine inputs, and constrain models (Sulzman 2007). As N cycles among different compartments of the ecosystem, many processes can cause isotopic discrimination: therefore examination of stable $\mathrm{N}$ isotope values can be used to shed extra light on ecosystem $\mathrm{N}$ cycling. $\mathrm{N}$ isotope values of ecosystem compartments can be influenced by multiple factors including i) uptake of differing $\mathrm{N}$ sources and forms with different isotopic signatures (partly mediated by rooting depth), ii) fixation of atmospheric $\mathrm{N}$, iii) fertilisation, iv) isotopic discrimination during uptake of $\mathrm{N}$ both by the plant and by symbiotic micro-organisms, $\mathrm{v}$ ) internal physiological fractionation (associated with uptake, translocation and loss of N), vi) changes in $\mathrm{N}$ demand, and vii) losses of nitrogen via denitrification and volatilisation (Shearer \& Kohl 1986; Erskine et al. 1998; Michelsen et al. 1996; Högberg et al. 1996; Nadehoffer et al. 1996; Högberg; 1997; Evans 2001, 2007; Robinson 2001; Kohzu et al. 65 2003; Hobbie et al. 2005; Houlton et al. 2006, 2007; Craine et al. 2009; Houlton \& Bai 2009; Makarov 2009). 
The use of $\mathrm{N}$ isotopes may be especially helpful in tropical regions where we have less information on $\mathrm{N}$ cycling and research is often conducted at remote locations with less well developed infrastructure to support complex research capacity. For example, in a comparison of soil and foliar $\delta^{15} \mathrm{~N}$ values, Martinelli et al. (1999) showed that tropical lowland forest leaves and soils were more enriched in ${ }^{15} \mathrm{~N}$ relative to temperate forests. Because of the loss of isotopically lighter $\mathrm{N}$ from the ecosystem via the fractionating pathways of nitrification and denitrification, it was suggested that the $\mathrm{N}$ cycle was more 'closed' in temperate forests and that gaseous losses of $\mathrm{N}$ from tropical lowland forests were higher. This was confirmed by Houlton et al. (2006) who used an isotopic approach to show high losses of nitrous oxide from tropical forests in Hawai'i.

In this study, we attempt to ascertain differences in the $\mathrm{N}$ cycle in two contrasting tropical montane forest types in the Blue Mountains of Jamaica; these are the 'mor ridge' and 'mull ridge' of Tanner (1977). The advantage to using this study system is that potential differences in $\mathrm{N}$ cycling due to climate (e.g. latitude, altitude, rainfall, and temperature) can be excluded as the two forest types are within close proximity $(<1 \mathrm{~km})$ to one another with minimal differences in climatic characteristics (Tanner 1980). We aim to examine variation in plant $\delta^{15} \mathrm{~N}$ values and relate this to soil $\delta^{15} \mathrm{~N}$ values, $\mathrm{N}$ availability, and rooting depth in the two forest types.

The reason for the formation of the mor ridge forest is not clear but is probably related to the chance aggregation of trees with more recalcitrant litter leading to the formation of the deep, acidic humus layer and consequently a positive feedback processes that amplified the development of this forest type. Previous work (Tanner 1977) suggested a slower rate of N mineralisation in this forest type and there may therefore be less nitrate available leading to the hypothesis that the mor ridge forest has a more 'closed' $\mathrm{N}$ cycle and therefore $\delta^{15} \mathrm{~N}$ values of both soils and plant material would be more negative. The goal of this study is to determine whether $\delta^{15} \mathrm{~N}$ values can be used as successful indicators of different rates of $\mathrm{N}$ cycling in these differing montane forest types.

\section{Methods}

Study sites The study sites are found at around $1600 \mathrm{~m}$ a.s.l. along John Crow ridge in the western Blue Mountains of Jamaica at $18^{\circ} 05^{\prime} \mathrm{N}, 76^{\circ} 39^{\prime} \mathrm{W}$ and have been described extensively by Tanner (1977). There is no comprehensive data on climatic conditions but 
annual rainfall is estimated at $2500 \mathrm{~mm}$ with an annual temperatures range from around $11^{\circ} \mathrm{C}$ to $20{ }^{\circ} \mathrm{C}$ (Shreve 1914; Tanner 1980). Whilst the remaining forests in the Blue Mountains are generally found on very steep terrain, the sites chosen for this study were situated along the Grand Ridge and, as such, were relatively flat. Two contrasting forest types were chosen for the study: 'mull ridge' which has trees up to 13-15 m tall (Soil $\mathrm{pH}$ : 3.6-4.0; Loss-on-ignition: 25-75 \%) was compared with 'mor ridge' which is a much more stunted forest formation with trees of up to 5-7 $\mathrm{m}$ tall found over an acidic, highly organic soil (Soil pH: 3.0; Loss-on-ignition: c. 95 \%) (Tanner 1977; Stewart 2000; F. Q. Brearley unpublished data).

Foliar samples In July-August 2006, foliar samples of mature leaves were collected from the two forest types. Samples were collected from mature, sunlit leaves of eight tree species from each forest type (three or six samples per species in each forest type) using a long115 handled pruner; these eight species accounted for c. 75-80\% of total basal area in each forest type (Tanner 1977). The species were: Alchornea latifolia (Euphorbiaceae), Clethra occidentalis (Clethraceae), Clusia havetioides (Clusiaceae; mor ridge only), Cyrilla racemiflora (Cyrillaceae), Hedyosmum arborescens (Chloranthaceae; mull ridge only), Lyonia octandra (Ericaceae), Pittosporum undulatum (Pittosporaceae), Podocarpus urbanii (Podocarpaceae) and Schefflera sciadophyllum (Araliaceae). Each sample was a composite of a number of leaves (dependent upon leaf size). The leaves were dried at $50^{\circ} \mathrm{C}$ (Brearley 2009) and the petioles and mid-rib removed. The leaves were then finely ground (Yellowline A10, IKAWerke, Staufen, Germany), sealed in air-tight plastic vials, and sent to the University of Washington, USA for isotope analyses (see 'Isotope analyses' below).

Soil and litter samples Six soil samples were collected from depths of 0-10, 10-20 and 20-30 cm using a metal corer in July-August 2006 from the two forest types (hereafter, 'bulk soils'). Bulked leaf litter samples were taken from an area of approximately $100 \mathrm{~cm}^{2}$ immediately adjacent to the holes made by the corer. Bulk soils and litter were dried at $50^{\circ}$ 130 C, finely ground, sealed in air-tight plastic vials, and sent for isotope analyses as above.

Soil N availability In May-June 2008 and again in February 2010, five samples of 15 to $20 \mathrm{~g}$ of fresh soil (from $0-10 \mathrm{~cm}$ depth only) were collected from the two forest types and shaken within 8 hours of collection with $100 \mathrm{ml}$ of $1 \mathrm{M} \mathrm{KCl}$ (1 minute of shaking by hand at $c .100 \mathrm{rpm}$ every ten minutes six times) and left to stand overnight (14-16 h) before being 
filtered (filter papers were pre-washed in $1 \mathrm{M} \mathrm{KCl}$ and rinsed in deionised water before use) and stored in $30 \mathrm{ml}$ vials (with $1 \mathrm{ml}$ of $1 \% \mathrm{HCl}$ added). Ammonium and nitrate were then determined on a Dionex ICS-2000 ion chromatography system with a CG16 guard column and CS16 separation column for ammonium and an AG18 guard column and AS18 separation column for nitrate (Dionex (UK), Camberley, Surrey, UK). To determine soil moisture content, fresh soils were placed in plastic bags to keep them moist and then dried at $105^{\circ} \mathrm{C}$ for 24 hours; soil weights were therefore adjusted accordingly. Nitrogen mineralisation and nitrification rates were assessed by incubating three or four c. $100 \mathrm{~g}$ portions of soil (on which the original ammonium and nitrate concentrations had been determined as above) in plastic bags immediately below the surface litter layer for 10 days (in May-June 2008) after which ammonium and nitrate concentrations were determined again. Mineralisation and nitrification rates were calculated as the difference in mineral $\mathrm{N}$ concentrations between the end and beginning of the incubations. PRS ${ }^{\mathrm{TM}}$ probes (WesternAg Innovations, Saskatoon, Saskatchewan, Canada) were inserted in the soil for 49 150 days in April-May 2009 (each of the eight samples consisted of two anion and two cation probes which were combined for analysis, except for one sample of a single probe of each type). After being taken out of the soil extraneous material was removed; they were then washed thoroughly in distilled water and shipped to Canada for analysis.

Soil ammonium and nitrate $\delta^{15} \mathrm{~N}$ values Ammonium and nitrate were captured on acidified filter papers using a modified diffusion methodology (Brooks et al. 1989; Claudia Schütz, pers. comm.) in July-August 2006 and again in May-June 2008. Twenty g of fresh soil (from 0$10 \mathrm{~cm}$ depth only) was shaken with $100 \mathrm{ml} 1 \mathrm{M} \mathrm{KCl}(1$ minute of shaking every ten minutes six times) and left to stand overnight (14-16 h) before being filtered into $300 \mathrm{ml}$ 160 glass jars. Fifty $\mathrm{mg}$ of $\mathrm{MgO}$ (pre-heated at $600^{\circ} \mathrm{C}$ for $4 \mathrm{hrs}$ ) was added to the $\mathrm{KCl}$ extract to convert $\mathrm{NH}_{4+}$ to $\mathrm{NH}_{3}$ which was captured on acidified [10 $\mu$ l of $\mathrm{KH}_{2} \mathrm{SO}_{4}\left(7 \% \mathrm{H}_{2} \mathrm{SO}_{4}\right.$, $\left.22 \% \mathrm{KSO}_{4}\right)$ pipetted on to the paper] squares of $1 \mathrm{~cm}^{2}$ Whatman GF/C filter paper elevated above the solution on stainless steel wire. The $\mathrm{KCl}$ extract was then incubated at ambient temperature (mean: $18.0^{\circ} \mathrm{C}$, range: $15.3-23.3^{\circ} \mathrm{C}$ ) for 4 days and swirled gently 165 daily. Filter papers were then removed and dried by placing them in a sealed plastic container containing silica gel. New filter papers were placed on the steel wires in the glass jars and $\mathrm{NO}_{3}$ - remaining in the solution was converted to $\mathrm{NH}_{4+}$ and subsequently to $\mathrm{NH}_{3}$ by adding $0.04 \mathrm{~g}$ of Devarda's alloy. After incubation for a further 3 days, the filter papers were removed and dried as above. Filter papers were sealed in plastic vials and sent for 
170 isotope analyses. Any filter papers which had a N content greater than one standard deviation from the mean $\mathrm{N}$ recovery expected as analysed by $\mathrm{KCl}$ extraction and ion chromatography (see above) were excluded from the subsequent statistical analyses; each forest type $x \mathrm{~N}$-species combination therefore had between four and seven replicates remaining.

175

Root biomass and depth distribution Root biomass (of live and dead roots up to $1 \mathrm{~mm}$ diameter) was estimated using standard techniques (Brearley 2011) from the same three depths as bulk soil samples were taken in both July-August 2006 and May-June 2008. The exponential decrease in root biomass was modelled using the equation of Gale \& Grigal 180 (1987):

$y=1-\beta^{\mathrm{d}}$

where $\mathrm{y}$ is the cumulative fraction of root biomass to a depth of $\mathrm{d} \mathrm{cm}$; with low $\beta$ values representing a steady decline with depth and high $\beta$ values representing a more rapid decline with depth.

Isotope analyses Around 1-2 mg of sample (or the whole of a filter paper) was weighed accurately into a tin capsule and the $\delta^{15} \mathrm{~N}$ (and $\% \mathrm{~N}$ ) value of all the samples were determined using a Thermo Finnegan Delta Plus XP isotope ratio mass spectrometer (Thermo Finnegan, Bremen, Germany) coupled to a Costech ECS 4010 elemental analyser 190 (Costech Analytical, Valencia, CA, USA) at the University of Washington, USA. The results are expressed in $\delta$ notation whereby $\delta^{15} \mathrm{~N}=\left[\left(R_{\text {sample }} / R_{\text {standard }}\right)-1\right] \times 1000$ when $R$ is the ratio of ${ }^{15} \mathrm{~N} /{ }^{14} \mathrm{~N}$. Precision of duplicate analyses of standard samples was better than $0.12 \%$ in all cases. Comparison to reference material of NIST peach or laboratory spinach leaves had a mean difference of $0.12 \%$.

\section{Results}

Whilst there was a significant difference between forest types in mean foliar $\delta^{15} \mathrm{~N}$ values, with the trees from the mor ridge forest showing more negative mean foliar $\delta^{15} \mathrm{~N}$ values of $-4.52 \%$ compared with $-2.98 \%\left(F_{1,61}=24.9, p<0.001\right.$; Figure 1$)$, there was also considerable variation in the foliar $\delta^{15} \mathrm{~N}$ values of the seven species sampled from both forest types $\left(F_{6,61}=8.22, p<0.001\right.$; Figure 1$)$, and a strong interaction between species and forest type $\left(F_{6,61}=2.98, p=0.013\right.$; Figure 1$)$. As an example, the difference in foliar $\delta^{15} \mathrm{~N}$ values in Pittosporum undulatum between the two forest types was about $3.9 \%$ whereas Cyrilla racemiflora had a minimal difference between the forest types of only $0.1 \%$ (n.b. 
205 Hedyosmum arborescens and Clusia bavetiodes were excluded from the above analyses as leaves were only collected from one forest type; if they are included, the mean values become $-4.62 \%$ and $-2.65 \%$ for mor and mull ridge forests). Whilst there was a significant effect of forest type when all species were combined, these were only actually significant for Pittosporum undulatum and Podocarpus urbanii after a Tukey's test $(\phi<0.05)$. There was no correlation between the species rankings of $\delta^{15} \mathrm{~N}$ values in the two forest types $\left(r_{\mathrm{s}}=0.39, p\right.$ $=0.34)$.

There were significant positive correlations between foliar $\delta^{15} \mathrm{~N}$ and $\% \mathrm{~N}$ in both forest types (Mor: $r=0.56 p<0.001$; Mull: $r=0.34, p=0.024$; Figure 2a). Similarly, there were positive correlations between foliar $\delta^{15} \mathrm{~N}$ and 10 year diameter (at $1.3 \mathrm{~m}$ ) growth rates between 1994 and 2004 (E. V. J Tanner, unpublished data) for both forest types (Mor: $r=$ 0.36, $p=0.43$; Mull: $r=0.62, p=0.14$; Figure 2b) although these were not statistically significant (Pittosporum undulatum was removed from this analysis as no individuals of this species were present in 1994).

Bulk soils (including the litter layer) were significantly more depleted in ${ }^{15} \mathrm{~N}$ in the mor ridge forests (by about $3 \%$ ) at all depths $\left(F_{1,34}=56.7, p<0.001\right.$; Figure 3); this was significant at all depths following a Tukey's test $(p<0.05)$ The bulk soil became increasingly enriched in ${ }^{15} \mathrm{~N}$ with depth in both forest types $\left(F_{3,34}=50.5, p<0.001\right.$; Figure 3) with the degree of enrichment being similar in both forest types indicated by the lack of a significant interaction term in the $\operatorname{ANOVA}\left(F_{3,34}=0.54, p=0.66\right.$; Figure 3$)$. In addition, bulked root samples similarly had lower $\delta^{15} \mathrm{~N}$ values in the mor ridge forest $\left(t_{12}=7.68, p<\right.$ 0.001; Figure 3). There was a negative correlation between bulk soil $\delta^{15} \mathrm{~N}$ and $\% \mathrm{~N}$ in both forest types (Mor: $r=-0.85, p<0.001$; Mull: $r=-0.65, p=0.009$ ).

Ammonium was found at greater concentrations, although not always significantly, in the mor ridge forest soil than the mull ridge forest soil across all methods and studies (Table 1). In contrast, depending upon the method used, values for nitrate varied from being slightly greater in mor ridge soil ( $\mathrm{KCl}$ extractions in 2008) to being fifteen-fold greater in mull ridge soil (PRS ${ }^{\mathrm{TM}}$ probes; Table 1). The nitrate:ammonium ratio was always greater (although never significantly so) in the mull ridge forest soil (Table 1). Nitrogen mineralisation and nitrification were greater in the mull ridge soils (Table 1). Using the data on soil bulk density from Tanner (1977) of 0.1 and $0.45 \mathrm{~g} \mathrm{~cm}^{-3}$ for mor and mull ridge forest, the 
amounts of both ammonium and nitrate were greater in the mull ridge forest soil when expressed on an area basis (data not shown) and mineralisation and nitrification were both over an order of magnitude greater in the mull ridge forest soil (Table 1).

Initial statistical tests suggested that year of collection (2006 vs. 2008) did not have an effect on $\delta^{15} \mathrm{~N}$ of soil ammonium and nitrate $(p>0.50)$ and hence both years were considered together in subsequent analyses. Ammonium in the upper soil layers $(0-10 \mathrm{~cm})$ was significantly more enriched in ${ }^{15} \mathrm{~N}$ in comparison to nitrate in both forest types $\left(F_{1,21}=\right.$ 36.7, $p<0.001$; Table 2) and both ammonium and nitrate in the mor ridge forest soils were depleted in ${ }^{15} \mathrm{~N}$ relative to the mull ridge forest soils $\left(F_{1,21}=4.00, p=0.058\right.$; Table 2$)$. In a separate analysis in which $\delta^{15} \mathrm{~N}$ of ammonium, nitrate and bulk soil (bulk soil data in Figure

250 3) were compared, in both forests' soils, $\delta^{15} \mathrm{~N}$ of ammonium was not significantly different to $\delta^{15} \mathrm{~N}$ of bulk soil (Tukey's test, $p>0.40$ ) in contrast to nitrate which was significantly depleted in ${ }^{15} \mathrm{~N}$ when compared to bulk soil (Tukey's test, $p<0.001$ ).

The root biomass of live and dead roots up to $1 \mathrm{~cm}$ diameter was approximately the same in the upper $10 \mathrm{~cm}$ of soil in both forest types but there was a more rapid decline in root biomass with depth in the mull ridge forests (Figure 4) indicated by significantly lower $\beta$ values in the mull ridge forest soil $\left(t_{16}=2.34 p=0.032\right)$.

\section{Discussion}

260 Foliar $\delta^{15} \mathbf{N}$ and comparisons with other studies

The values for foliar $\delta^{15} \mathrm{~N}$ were, in general, very low (Figure 1) when compared to, for example, tropical lowland forests in French Guiana where no leaf sample had a $\delta^{15} \mathrm{~N}$ value of less than -0.6\% (Roggy et al. 1999) or in Brazil (Ometto et al. 2006) where the mean value was $5.8 \%$ and the lowest value $0.9 \%$. The values were more similar to those from Hawai'ian forests with an overall of mean of $-5.1 \%$ (Vitousek et al. 1989). Indeed, the foliar $\delta^{15} \mathrm{~N}$ values are comparable to, if not lower than, many samples from temperate forests which are considered to be more $\mathrm{N}$ limited than tropical forests where the mean value for foliage in temperate forests in the compilation of Martinelli et al. (1999) was -2.8 $\%$.

If we calculate a weighed foliar $\delta^{15} \mathrm{~N}$ average for each forest type [weighted by species basal area; data in Tanner (1977)] then the values are $-2.94 \%$ for mor ridge forest and $-2.36 \%$ o 
for mull ridge forest. For the mor ridge forest, this is less than the value for the bulked leaf litter, suggesting some isotopic discrimination related to foliar $\mathrm{N}$ re-absorption in contrast to studies by Garten (1993) and Kolb \& Evans (2002) who found little evidence for isotopic discrimination during this process.

Foliage was depleted in ${ }^{15} \mathrm{~N}$ relative to the soil as anticipated, due to physiological (or mycorrhizal mediated) fractionation during $\mathrm{N}$ uptake (Michelsen et al. 1996; Evans 2001;

280 Robinson 2001; Amundsen et al. 2003). The difference between surface bulk soil (0-10 cm) samples and foliage was 3-4 \%o as predicted by Amundsen et al. (2003) and Houlton et al. (2007). When the data was compared with the global database of Craine et al. (2009), the values were about $3 \%$ lower than might be expected as predicted by climate, foliar $\mathrm{N}$ concentration and type of mycorrhizal association (J. M. Craine, pers. comm.). Although we might expect, given the hypothesis of $\mathrm{N}$-limitation in these forests, complete uptake of available $\mathrm{N}$ and hence little fractionation.

Mycorrhizas and root symbioses There were no differences in foliar $\delta^{15} \mathrm{~N}$ in relation to symbiotic micro-organisms within the roots of the various species. Whilst the mycorrhizal associations of the species found in this montane forest are not known for certain, we can make informed guesses that most of the species will form arbuscular mycorrhizas (AM). Podocarpus urbanii, in addition, has root nodules (F. Q. Brearley, pers. obs.), but, as found by other studies (Baylis et al. 1963; Russell et al. 2002), these actually form a housing for AM fungi and do not appear to be providing atmospheric $\mathrm{N}$ to this species as its foliar $\delta^{15} \mathrm{~N}$ values were significantly less than $0 \%$ and fell well within the values for the other species studied. The AM status of the nodules of $P$. urbanii has been confirmed by molecular detection of AM fungi using the primers of Helgason et al. (1998) (F. Q. Brearley, unpubl. data). Lyonia octandra is expected to have ericoid mycorrhizas and all other species to have AM but there was no difference in foliar $\delta^{15} \mathrm{~N}$ between them: perhaps due to maximal $\mathrm{N}$ 300 uptake and, hence, minimal isotopic fractionation. Elbers (1996, in Hafkenscheid 2000) showed a greater soil fungal hyphal length in the mor ridge forest soil and, therefore, a greater reliance on mycorrhizal fungi to supply $\mathrm{N}$ in the mor ridge forest may be leading to more depleted foliar $\delta^{15} \mathrm{~N}$ values (Brearley et al. 2003; Hobbie et al. 2005).

305 Rooting depth To examine whether the differing $\delta^{15} \mathrm{~N}$ values might be related to rooting depth of the trees, soil cores were taken from the two forest types and roots extracted. 
The more rapid decline in root mass with depth in the mull ridge forests (Figure 4) suggested that trees in the mor ridge will be taking soil $\mathrm{N}$ from, on average, a slightly greater depth than in the mull ridge. This is corroborated by the results of Stewart (2000) who noted that root growth into ingrowth cores in the mor ridge soils was evenly distributed along the $15.5 \mathrm{~cm}$ deep cores, but was mostly in the top third of the core in the mull ridge soils. However, this process would lead to ${ }^{15} \mathrm{~N}$-enriched foliage which is not what is seen, suggesting that other factors are cancelling out any potential changes in $\delta^{15} \mathrm{~N}$ values due to rooting depth. A more detailed study of root patterns on a species-by-species basis would be helpful to provide more information on patterns of $\mathrm{N}$ uptake in these forests.

Ammonium/nitrate preference In agreement with our study (Table 2), it has often been shown that soil nitrate is depleted in ${ }^{15} \mathrm{~N}$ relative to ammonium (Garten 1993; Koba et al. 1998; Miller \& Bowman 2002; Schimann et al. 2008; Cheng et al. 2010) and, therefore, species with a preference for nitrate over ammonium (within a given soil type) would have lower $\delta^{15} \mathrm{~N}$ values. In ecosystems where there was not expected to be a significant loss of nitrate, species taking up proportionally more nitrate had more negative $\delta^{15} \mathrm{~N}$ values relative to those taking up ammonium (Miller \& Bowman 2002). Indeed, $64 \%$ of the variation in $\mathrm{N}$ isotope ratios between the co-existing alpine grassland species was explained by their ammonium:nitrate uptake ratios in the study of Miller \& Bowman (2002). It is acknowledged that there may be temporal changes in $\delta^{15} \mathrm{~N}$ values for ammonium and nitrate but the lack of significant differences between our two sampling dates suggests a consistency of this general pattern in the montane forest soils studied here. Interestingly, it appears that, although nitrate is being produced in these forest soils, and in some cases is the dominant form of inorganic nitrogen [Table 1; although note that the time between sample collection and extraction may have increased nitrate values in the soils; see Arnold et al. (2008)], most trees are using nitrogen with an isotopic value closer to that of ammonium. This might explain the somewhat counter-intuitive results of Brookshire et al.

335 (2012) who found high losses of nitrate from montane forests that are generally thought to be $\mathrm{N}$-limited as various aspects of their ecosystem productivity respond to additions of nitrogen fertiliser (as urea) (Adamek et al. 2011; Tanner et al. 1990).

In addition, leaves in the mor ridge were closer to the bulk soil $\delta^{15} \mathrm{~N}$ (Figure 1, Table 2) suggesting greater ammonium uptake as it has been shown that soil ammonium is 
isotopically more similar to bulk soil $\mathrm{N}$ than is soil nitrate, both in this study (Table 2) and by Koba et al. (1998). To test the relative importance of nitrate nutrition, relative to ammonium nutrition, in these Jamaican forests it would be helpful to examine leaf nitrate reductase activity (e.g. Michelsen et al. 1996; Nadelhoffer et al. 1996; Miller \& Bowman 2002) or conduct a soil ${ }^{15} \mathrm{~N}$ labelling experiment.

A key question arising from this study is why there was a large change in the species rankings of foliar $\delta^{15} \mathrm{~N}$ values between the two forest types? There was a consistent change in soil $\delta^{15} \mathrm{~N}$ values between forest types and thus this would have affected all species equally. We consider it most likely that a change in competitive interactions between the species in the different forest types - either by changing the depth at which they foraged for soil resources or, perhaps more likely, changing uptake of the different forms of $\mathrm{N}$ available in the soil, led to this change in rankings. Houlton et al. (2007) showed how a number of tropical Hawai'ian plants changed preference for differing $\mathrm{N}$ forms with increasing rainfall suggesting a strong flexibility in $\mathrm{N}$ usage in these species. The flexibility of $\mathrm{N}$ use strategies in the Jamaican plants remains to be ascertained experimentally but our isotope results do suggest some flexibility of $\mathrm{N}$ form preference on differing soil types and that this flexibility differed between species. Interestingly, the species with the greatest apparent flexibility was Pittosporum undulatum which may be a contributing factor to its successful invasion in this area (Goodland \& Healey 1996; Bellingham et al. 2005).

\section{Soil $\delta^{15} \boldsymbol{N}$ and comparisons with other studies}

Bulk soil $\delta^{15} \mathrm{~N}$ values were also low (Figure 3) and, especially for the mor ridge forest, were some of the lowest recorded. Indeed, they are similar to sites which have very young soils with minimal $\mathrm{N}$ content such as soils developing on glacier forefronts (Hobbie et al. 2005) or young lava flows (Vitousek et al. 1989). Brearley et al. (2011) have shown lowland tropical soil $\delta^{15} \mathrm{~N}$ values of around $2 \%$ to $6 \%$ across a range of sites and values in Brazilian soils were around $8 \%$ in surface horizons, falling to around $11 \%$ at $50 \mathrm{~cm}$ depth (Ometto et al. 2006). Our Jamaican $\delta^{15} \mathrm{~N}$ values were more similar to, although still

370 lower than, those from other montane tropical forests at $1500 \mathrm{~m}$ in Ecuador (2.3\% \% Arnold et al. 2009) and $1700 \mathrm{~m}$ in Borneo (0.3 \%; Kitayama \& Iwamoto 2001). The most similar values were from ridge soils at $2000 \mathrm{~m}$ altitude in Ecuador of $-1.3 \%$ (Wolf et al. 2011). 
375 There was considerable enrichment of ${ }^{15} \mathrm{~N}$ with depth in both forests (Figure 3) as seen in other studies (Nadelhoffer \& Fry 1988, 1994; Koba et al. 1998; Boeckx et al. 2005; Cheng et al. 2010), this being attributed to processes occurring during $\mathrm{N}$ mineralisation which favour ${ }^{14} \mathrm{~N}$ as a substrate over ${ }^{15} \mathrm{~N}$, thereby leaving (microbially) ${ }^{15} \mathrm{~N}$ enriched products in the soil which will form organic matter over time (Nadelhoffer \& Fry 1994; Högberg 1997).

380 During organic matter formation and stabilisation, the accumulation of ${ }^{15} \mathrm{~N}$-enriched compounds from decay products will lead to the enrichment of soil ${ }^{15} \mathrm{~N}$ over time. Enrichment of soil ${ }^{15} \mathrm{~N}$ is also achieved by the input of ${ }^{15} \mathrm{~N}$-depleted foliage to upper soil layers (Nadelhoffer \& Fry 1988) and preferential mineralisation of ${ }^{15} \mathrm{~N}$-depleted compounds.

385

\section{$\delta^{15} \mathrm{~N}$ and $\mathbf{N}$ cycling rates}

It has been suggested that soil and root $\delta^{15} \mathrm{~N}$ values can be used as an indicator of rates of $\mathrm{N}$ cycling between sites (Martinelli et al. 1999; Templer et al. 2007). The soils and roots were significantly more depleted in ${ }^{15} \mathrm{~N}$ in the Jamaican mor ridge forests (by about $3 \%$ ) at 390 all depths (Figure 3) confirming slower rates of $\mathrm{N}$ mineralisation and nitrification (Table 1) and a more 'closed' $\mathrm{N}$ cycle. This includes the litter layer and therefore suggests that there is more $\mathrm{N}$ available in the mull ridge forest as losses of $\mathrm{N}$ from systems with excess $\mathrm{N}$ are more likely to be fractionating (nitrate leaching and denitrification) compared to more Nlimited systems where losses may be minimal and/or by non fractionating pathways (e.g. loss of dissolved organic nitrogen: Perakis \& Hedin 2002). Various studies have shown a positive correlation between nitrification rates and plant $\delta^{15} \mathrm{~N}$ (Garten 1993; Garten \& Van Miegroet 1994; Pardo et al. 2006; Templer et al. 2007; Cheng et al. 2010) in broad agreement with our study where the mull ridge forests had greater nitrification (and $\mathrm{N}$ mineralisation) rates (Table 1) and less negative foliar $\delta^{15} \mathrm{~N}$ values (Figure 1). However, it should be noted

400 that there were differences in the absolute values for mineral $\mathrm{N}$ values and transformations obtained by the different studies in Table 1. There are a number of reasons for this that could include the time taken to process samples between collection and extraction (Arnold et al. 2008), increased $\mathrm{N}$ deposition rates over the 30-year period (not quantified) and whether the incubations were conducted in situ or in warmer lowland climates (as in 405 Tanner's 1977 study). In addition, there may be some issues associated with the use of PRS $^{\mathrm{TM}}$ probes including severing of roots leading to less competition for nitrate, nitrification occurring on the probes or uptake of ammonium from the probes. 
It would be very interesting to compare the $\delta^{15} \mathrm{~N}$ values in this study with those of Tanner

410 (1977) to assess if $\mathrm{N}$ cycling patterns may have changed in a manner similar to Hietz et al. (2011) who showed an increase in foliar $\delta^{15} \mathrm{~N}$ values in lowland forests in Panama suggesting increased $\mathrm{N}$ deposition over a $c .40$ year time period. We may well expect to see similar patterns in these Jamaican forests although this has not been directly measured.

415 A number of authors (Högberg 1997; Pardo et al. 2006; Templer et al. 2007) consider below-ground (i.e. root) $\delta^{15} \mathrm{~N}$ values to be a better indicator of the relative rates of $\mathrm{N}$ cycling which concurs with our study, as we found considerable variation in foliar $\delta^{15} \mathrm{~N}$ values between species (c. $4 \%$; Figure 1), most likely due to internal physiological fractionation processes which may hide any soil-based variation between sites.

\section{Conclusions}

We have shown how $\delta^{15} \mathrm{~N}$ values of soils and roots are more negative in mor ridge tropical montane forests of Jamaica suggesting a tighter $\mathrm{N}$ cycle and hence this element is suggested to be more limiting in this forest type. $\delta^{15} \mathrm{~N}$ values varied between tree species, and the rankings changed between soil types, indicating that the use of foliar $\delta^{15} \mathrm{~N}$ values are less helpful in assessing $\mathrm{N}$ limitation due to the different responses of species to the two soil types and the relative uptake of different $\mathrm{N}$ forms (which appeared to be a preference for ammonium in most cases). The physiological processes underlying this inter-specific variation require further study but are likely to be due to differential preferences/uptake for

430 ammonium or nitrate. It will be valuable to assess how the $\mathrm{N}$ cycle is altered in these tropical montane forests in the future with increasing $\mathrm{N}$ deposition.

\section{Acknowledgements}

I am indebted to Ed Tanner (University of Cambridge) for his continued support and encouragement of this research. Many thanks to Ben Harlow (University of Washington) for isotope analysis; thanks also to Kurt McLaren and Jane Cohen (University of the West Indies) for advice and logistical support, Raymond Ramdon (Ministry of Agriculture, Jamaica) for permission to use Cinchona Botanic Gardens as a base, the staff of the gardens for their assistance, Claudia Schütz (Technischen Universität München) for advising on isotopic analysis of ammonium and nitrate, Shauna-Lee Chai (University of Cambridge) for placing and collecting the PRSTM probes, and Steve Hoon (Manchester Metropolitan University) for help in modelling root biomass. This study was financially supported by the British Ecological Society, Dalton Research Institute 
(Manchester Metropolitan University), Percy Sladen Memorial Fund, Trinity College Dublin Association and Trust, and WesternAg Innovations. 


\section{References}

Adamek M, Corre MD, Hölscher D (2009) Early effect of elevated nitrogen input on above-ground net primary productivity of a lower montane rain forest, Panama. J Trop Ecol 25:637-547.

Amundsen R, Austin AT, Schuur EAG, Yoo K, Matzek VA, Kendall C, Uebersax A, Brenner DL, Baisden WT (2003) Global patterns of the isotopic composition of soil and plant nitrogen. Glob Biogeochem Cycles 17: Art. 1031.

Arnold J, Corre MD, Veldkamp E (2009) Soil N cycling in old-growth forests across an Andosol toposequence in Ecuador. For Ecol Manage 257: 2079-2087.

Arnold J, Corr MD, Veldkamp E (2008) Cold storage and laboratory incubation of intact soil cores do not reflect in-situ nitrogen cycling rates of tropical forest soils. Soil Biol Biochem 40: 2480-2483.Baylis GTS, McNabb RFR, Morrison TM (1963) The mycorrhizal nodules of podocarps. Trans Br Mycol Soc 46: 378-384.

Bellingham PJ, Tanner EVJ, Healey JR (2005) Hurricane disturbance accelerates invasion by the alien tree Pittosporum undulatum in Jamaican montane rain forests. J Veg Sci 16: 675-684.

Boeckx P, Paulino L, Oyarzún C, van Cleemput O, Godoy R (2005) Soil $\delta^{15} \mathrm{~N}$ patterns in old-growth forests of southern Chile as integrator for N-cycling. Isot Environ Health Stud 41: 249-259.

Brearley FQ (2009) How does sample preparation affect the $\delta^{15} \mathrm{~N}$ values of terrestrial ecological materials? J Plant Nutr Soil Sci 172: 461-463.

Brearley FQ (2011) Below-ground secondary succession in tropical forests of Borneo. J Trop Ecol 27: 413420.

Brearley FQ, Press MC, Scholes JD (2003) Nutrients obtained from leaf litter can improve the growth of dipterocarp seedlings. New Phytol 160: 101-110.

Brearley FQ, Fine PVA, Perreijn K (2011) Does nitrogen availability have greater control over the formation of tropical heath forests than waster stress? A hypothesis based on nitrogen isotope ratios. Acta Amazon 49: 589-592.

Brooks PD, Stark JM, McInteer, BB Preston T (1989) Diffusion method to prepare soil extracts for automated nitrogen-15 analysis. Soil Sci Soc Am J 53: 1707-1711.

Brookshire ENJ, Hedin LO, Newbold, JD, Sigman DM, Jackson JK (2012) Sustained losses of bioavailable nitrogen from montane tropical forests. Nature Geosci (in press).

Cheng S-L, Fang H-J, Yu G-R, Zhu T-H, Zheng J-J (2010) Foliar and soil ${ }^{15} \mathrm{~N}$ natural abundances provide field evidence on nitrogen dynamics and temperate and boreal forest ecosystems. Plant Soil 337: 285297.

Craine JM, Elmore AJ, Aidar MPM, Bustamante M, Dawson TE, Hobbie EA, Kahman A, Mack MC, McLauchlan KK, Michelsen A, Nardoto GB, Pardo LH, Peñuelas J, Reich PB, Schuur EAG, Stock WD, Templer PH, Virginia RH, Welker JM, Wright IJ (2009) Global patterns of foliar nitrogen isotopes and their relationships with climate, mycorrhizal fungi, foliar nutrient concentrations, and nitrogen availability. New Phytol 183: 980-992.

Erskine PD, Bergstrom DM, Schmidt S, Stewart GR, Tweedie CE, Shaw JD (1998) Subantarctic Macquarie Island - a model ecosystem for studying animal-derived nitrogen sources using ${ }^{15} \mathrm{~N}$ natural abundance. Oecologia 117: 187-193. 
Evans RD (2001) Physiological mechanisms influencing plant nitrogen isotope composition. Trends Plant Sci 6: 121-126.

Evans RD (2007) Soil nitrogen isotope composition. In: K Lajtha, RH Mitchener (eds) Stable Isotopes in Ecology and Environmental Science, 2nd Edition. Blackwell Scientific, Oxford, UK, pp. 83-98.

Gale MR, Grigal DF (1987) Vertical root distributions of northern tree species in relation to successional status. Can J For Res 17: 829-834.

Garten Jr CT (1993) Variation in foliar ${ }^{15} \mathrm{~N}$ abundance and the availability of soil nitrogen on Walker Branch watershed. Ecology 74: 2098-2113.

Garten Jr. CT, Van Miegroet H (1994) Relationships between soil nitrogen dynamics and natural ${ }^{15} \mathrm{~N}$ abundance in plant foliage from Great Smoky Mountains National Park. Can J. For. Res. 24, 16361645.

Goodland TCR, Healey JR (1996) The invasion of Jamaican montane rainforests by the Australian tree Pittosporum undulatum. School of Agricultural and Forest Sciences, University of Wales, Bangor, UK. http://pages.bangor.ac.uk/ afs101/iwpt/pittorep.pdf. Accessed 19 February 2012.

Hafkenscheid RLLJ (2000) Hydrology and biogeochemistry of tropical montane rain forests of contrasting stature in the Blue Mountains, Jamaica. PhD Dissertation, Vrije Universiteit, Amsterdam, The Netherlands.

Helgason T, Daniell TJ, Husband R, Fitter AH, Young JPW (1998) Ploughing up the wood-wide web? Nature 394: 431.

Hietz P, Turner BL, Wanek W, Richter A, Nock CA, Wright SJ (2011) Long-term change in the nitrogen cycle of tropical forests. Science 334: 664-666.Hobbie EA, Jumpponen A, Trappe J (2005) Foliar and fungal ${ }^{15} \mathrm{~N}:{ }^{14} \mathrm{~N}$ ratios reflect development of mycorrhizae and nitrogen supply during primary succession; testing analytical methods. Oecologia 146: 258-268.

Högberg P (1997) ${ }^{15} \mathrm{~N}$ natural abundance in soil-plant systems New Phytol 137: 179-203 \& 139: 595.

Högberg P, Högbom L, Schinkel H, Högberg MN, Johannisson C, Wallmark H (1996) ${ }^{15} \mathrm{~N}$ abundance of surface soils, roots and mycorrhizas in profiles of European forest soils. Oecologia 108: 207-214.

Houlton BZ, Bai E (2009) Imprint of denitrifying bacteria on the global terrestrial biosphere. Proc Natl Acad Sci USA 106: 21713-21716.

Houlton BZ, Sigman DM, Hedin LO (2006) Isotopic evidence for large gaseous losses from tropical rainforests. Proc Natl Acad Sci USA 103: 8745-8750.

Houlton BZ, Sigman DM, Schuur EAG, Hedin LO (2007) A climate-driven switch in plant nitrogen acquisition within tropical forest communities. Proc Natl Acad Sci USA 104: 8902-8906.

Huang BL, Lü CQ, Wu B, Fan LQ (2007) A rhizobia strain isolated from root nodule of gymnosperm Podocarpus macrophyllus. Sci China Ser C Life Sci 50: 228-233.

Kitayama K, Iwamoto K (2001) Patterns of natural ${ }^{15} \mathrm{~N}$ abundance in the leaf-to-soil continuum of tropical rain forests differing in N availability on Mount Kinabalu, Borneo. Plant Soil 229: 203-212.

Koba K, Tokuchi N, Yoshioka T, Hobbie EA, Iwatsubo G (1998) Natural abundance of nitrogen-15 in a forest soil. Soil Sci Soc Am J 62: 778-781.

Kohzu A, Matsui K, Yamada T, Sugimoto A, Fujita N (2003) Significance of rooting depth in mire plants: evidence from natural ${ }^{15} \mathrm{~N}$ abundance. Ecological Research 18: 257-266. 
Kolb KJ, Evans RD (2002) Implications of leaf nitrogen recycling on the nitrogen isotope composition of deciduous plant tissues. New Phytol 156: 57-64.

Makarov MI (2009) The nitrogen isotopic composition in soils and plants: its use in environmental studies (a review). Eurasian Soil Sci 42: 1432-1445.

Martinelli LA, Piccolo MC, Townsend AR, Vitousek PM, Cuevas E, McDowell W, Robertson GP, Santon OC, Treseder KK (1999) Nitrogen stable isotopic composition of leaves and soil: tropical versus temperate forests. Biogeochem 46: 45-65.

McKane RB, Johnson LC, Shaver GR, Nadelhoffer KJ, Rastetter EB, Fry B, Giblin AE, Kielland K, Kwaitkowski BL, Laundre JA, Murray G (2002) Resource-based niches proves a basis for plant species diversity and dominance in arctic tundra. Nature 415: 68-71.

Michelsen A, Schmidt IK, Jonasson S, Quarmby C, Sleep D (1996) Leaf ${ }^{15} \mathrm{~N}$ abundance of subarctic plants provides field evidence that ericoid, ectomycorrhizal and non- and arbuscular mycorrhizal species access different sources of soil nitrogen. Oecologia 105: 53-63.

Miller AE, Bowman WD (2002) Variation in nitrogen-15 natural abundance and nitrogen uptake traits among co-occurring alpine species: do species partition by nitrogen form? Oecologia 130, 609-616.

Nadelhoffer KJ, Fry B (1988) Controls on natural nitrogen-15 and carbon-13 abundances in forest soil organic matter. Soil Sci Soc Am J 52: 1633-1640.

Nadelhoffer KJ, Fry B (1994) Nitrogen isotope studies in forest ecosystems. In: K Lajtha, RH Michener (eds) Stable Isotopes in Ecology and Environmental Sciences. Blackwell Scientific, Oxford, UK, pp. 22-44.

Nadelhoffer KJ, Shaver GR, Fry B, Giblin AE, Johnson L, McKane RB (1996) ${ }^{15} \mathrm{~N}$ natural abundance and N use by tundra plants. Oecologia 107: 386-394.

Ometto JPHB, Ehleringer JR, Domingues TF, Berry JA, Ishida FY, Mazzi E, Higuchi N, Flanagan LB, Nardoto GB, Martinelli LA (2006) The stable carbon and nitrogen isotopic composition of vegetation in tropical forests of the Amazon basin, Brazil. Biogeochem 79: 251-274.

Ortiz-Zayas JR, Cuevas E, Mayol-Bracero OL, Donoso L, Trebs I, Figueroa-Nieves D, McDowell WH (2006) Urban influences on the nitrogen cycle in Puerto Rico. Biogeochem 79: 109-133.

Pardo LH, Templer PH, Goodale CL, Duke S, Groffman PM, Adams MB, Boeckx P, Boggs J, Campbell JL, Colman B, Compton JE, Emmett BA, Gunderson P, Kjønaas OJ, Lovett GM, Mack M, Magill AH, Mbila M, Mitchell MJ, McGee G, McNulty SG, Nadelhoffer KJ, Ollinger SV, Ross D, Rueth HM, Rustad LE, Schaberg PG, Schiff SL, Schleppi P, Spoelstra J, Wessel W (2006) Regional assessment of $\mathrm{N}$ saturation using foliar and root $\delta^{15} \mathrm{~N}$. Biogeochem 80: 143-171.

Perakis SS, Hedin LO (2002) Nitrogen loss from unpolluted South American forests mainly via dissolved organic compounds. Nature 415: 416-419.

Phoenix GK, Hicks WK, Cinderby S, Kuylenstierna JCI, Stock WD, Dentener FJ, Giller KE, Austin AT, Lefroy RDB, Gimeno BS, Ashmore MR \& Ineson P (2006). Atmospheric nitrogen deposition in world biodiversity hotspots: the need for a greater global perspective in assessing $\mathrm{N}$ deposition impacts. Glob Change Biol 12: 470-476.

Robinson, D. (2001) $\delta^{15} \mathrm{~N}$ as an integrator on the nitrogen cycle. Trends Ecol Evol 16: 153-162.

Roggy J-C, Prévost MF, Garbaye J, Domenach A-M (1999) Nitrogen cycling in the tropical rain forest of French Guiana: comparison of two sites with contrasting soil types using $\delta^{15} \mathrm{~N}$. Oecologia 120: 171182. 
Russell AJ, Bidartondo MI, Butterfield BG (2002) The root nodules of the Podocarpaceae harbour arbuscular mycorrhizal fungi. New Phytol 156: 283-295.

Schimann H, Ponton S, Hättenschwiler S, Ferry B, Lensi R, Domenach A-M, Roggy J-C (2008) Differing nitrogen use strategies of two tropical rainforest late successional tree species in French Guiana: evidence from ${ }^{15} \mathrm{~N}$ natural abundance and microbial activities. Soil Biol Biochem 40: 487-494.

Shearer G, Kohl DH (1986) $\mathrm{N}_{2}$-fixation in field settings: estimations based on ${ }^{15} \mathrm{~N}$ natural abundance. Aust J Plant Physiol 13: 699-756.

Shreve F (1914) A montane rain forest. a contribution to the physiological plant geography of Jamaica. Publ Carnegie Inst 199: 1-110.

Stewart CG (2000) A test of nutrient limitation in two tropical montane forests using root ingrowth cores. Biotropica 32: 369-373.

Sulzman EW (2007) Stable isotope chemistry and measurement: a primer. In: K Lajtha, RH Michener (eds) Stable Isotopes in Ecology and Environmental Sciences, 2nd Edition. Blackwell Scientific, Oxford, UK, pp. 1-21.

Tanner EVJ (1977) Four montane rain forests of Jamaica: a quantitative characterization of the floristics, the soils and the foliar mineral levels and a discussion of the interrelations. J Ecol 65: 883-918.

Tanner EVJ (1980) Litterfall in montane rain forests of Jamaica and its relation to climate. J Ecol 68: 833848.

Tanner EVJ, Kapos V, Freskos S, Healey JR, Theobald AM (1990) Nitrogen and phosphorus fertilization of Jamaican montane forest trees. J Trop Ecol 6: 231-238.

Tanner EVJ, Vitousek PM, Cuevas E (1998) Experimental investigation of nutrient limitation of forest growth on wet tropical mountains. Ecology 79: 10-22.

Templer PH, Arthur MA, Lovett GM, Weathers KC (2007) Plant and soil natural abundance of $\delta^{15} \mathrm{~N}$ : indicators of relative rates of nitrogen cycling in temperate forest ecosystems. Oecologia 153: 399406.

Vitousek PM, Shearer G, Kohl DH (1989) Foliar ${ }^{15} \mathrm{~N}$ natural abundance in Hawaiian rainforest: patterns and possible mechanisms. Oecologia 78: 383-388. Wolf K, Veldkamp E, Homeier J, Martinson GO (2011) Nitrogen availability links forest productivity, soil nitrous oxide and nitric oxide fluxes of a tropical montane forest in southern Ecuador. Glob Biogeochem Cycle 25: GB4009. 
Figure 1 Foliar $\delta^{15} \mathrm{~N}$ values for nine tree species in two contrasting forest types in the Blue Mountains of Jamaica. All values are mean \pm standard error.

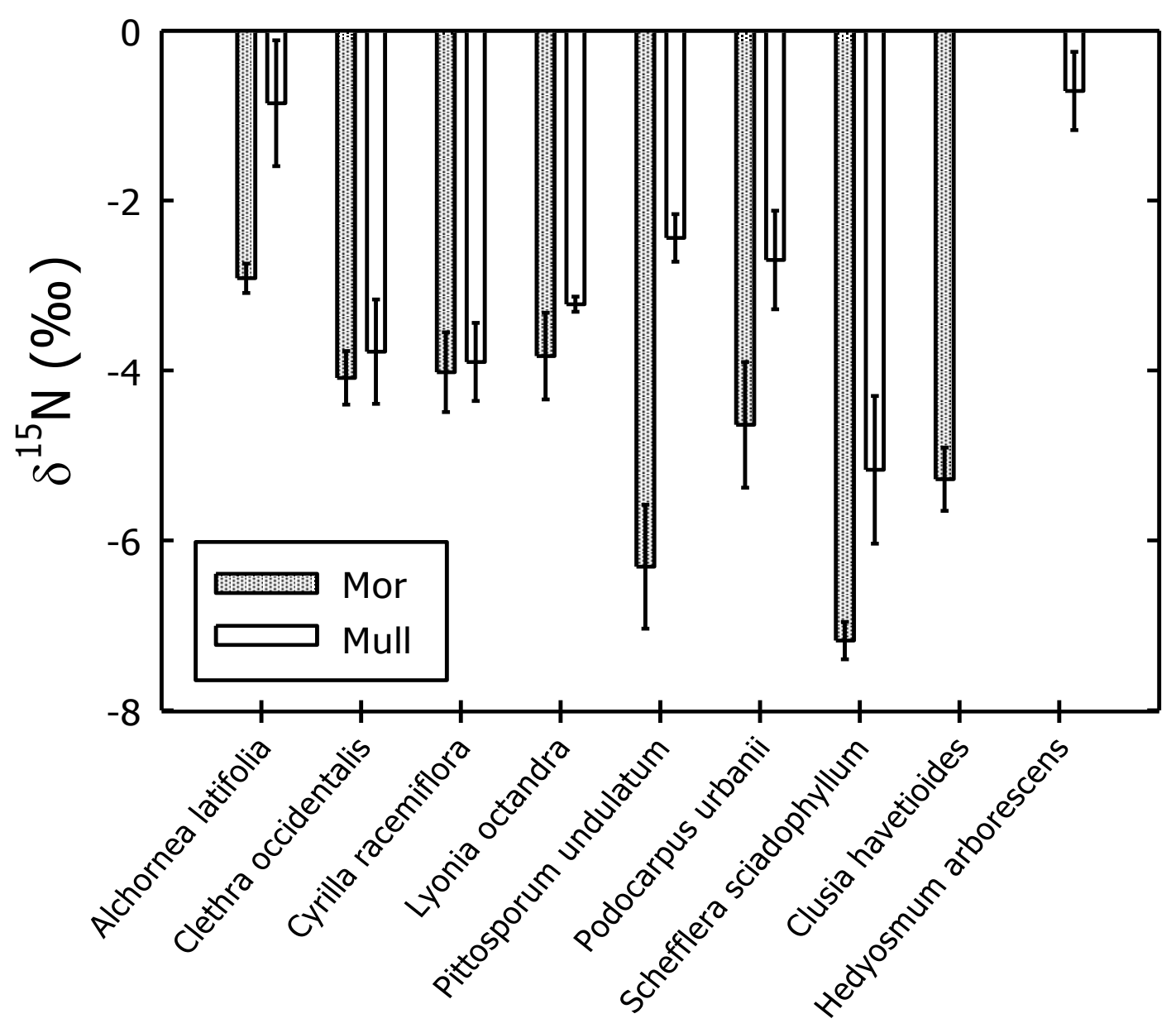


Figure 2 Positive correlations between foliar $\delta^{15} \mathrm{~N}$ and (a) leaf foliar $\mathrm{N}$ and (b) tree absolute growth rates (AGR) between 1994 and 2004 in two contrasting forest types in the Blue Mountains of Jamaica.
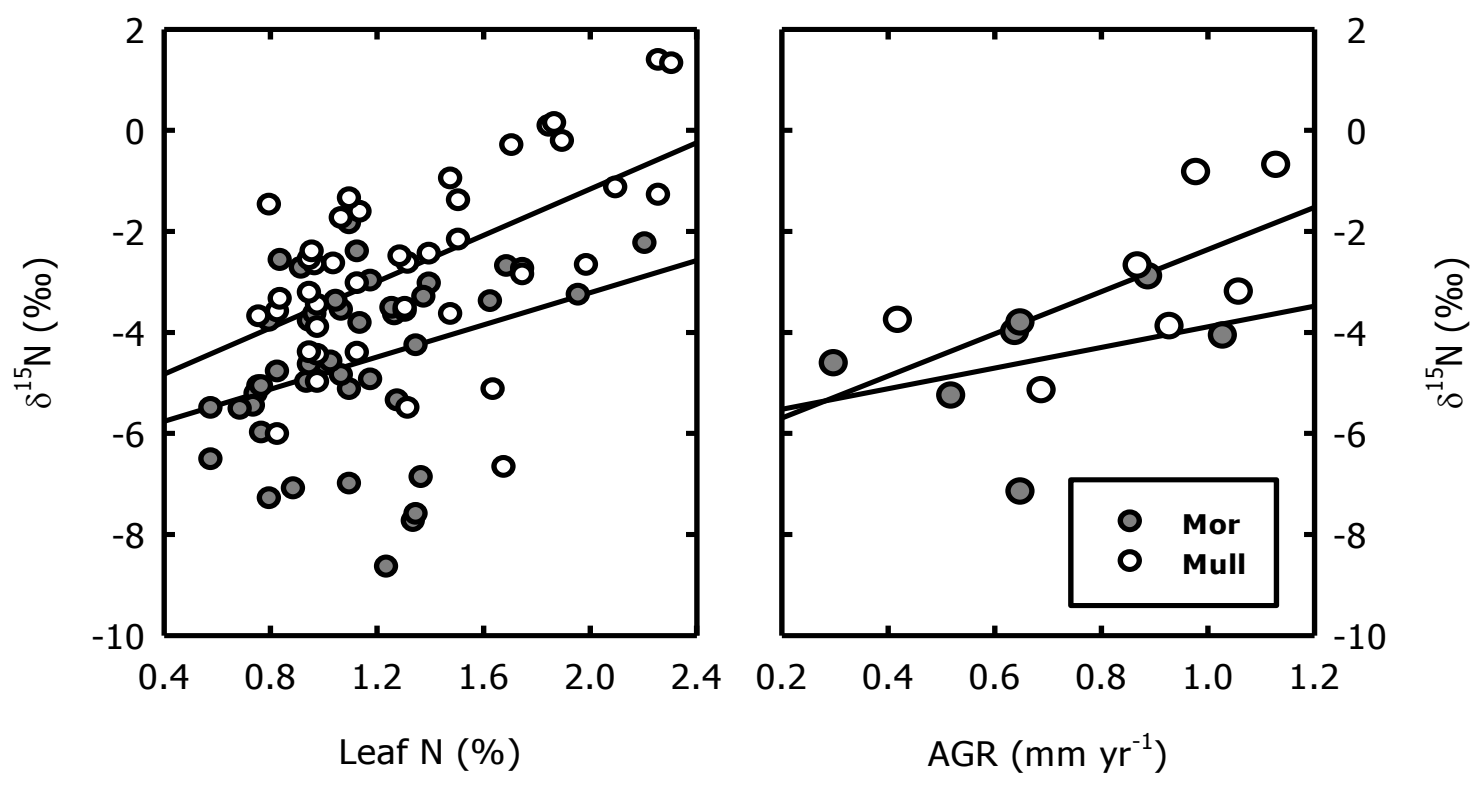
Figure 3 Bulk soil, root, and leaf litter $\delta^{15} \mathrm{~N}$ values in two contrasting forest types in the Blue Mountains of Jamaica. All values are mean \pm standard error.

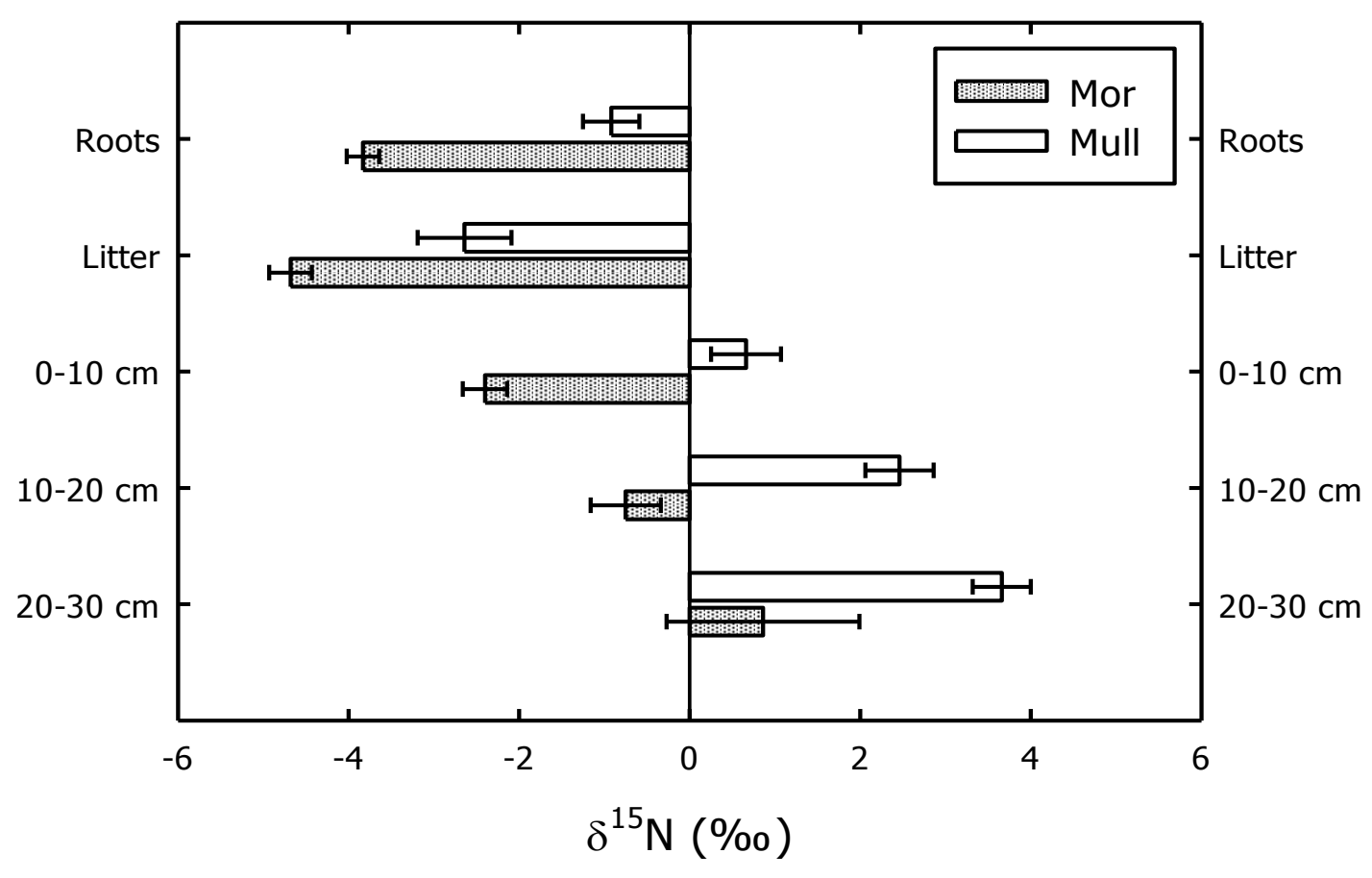


Figure 4 Root biomass $(<1 \mathrm{~mm}$ diameter $)$ at thee depths in two contrasting forest types in the Blue Mountains of Jamaica and the corresponding $\beta$ values describing the exponential decline with depth. All values are mean \pm standard error.

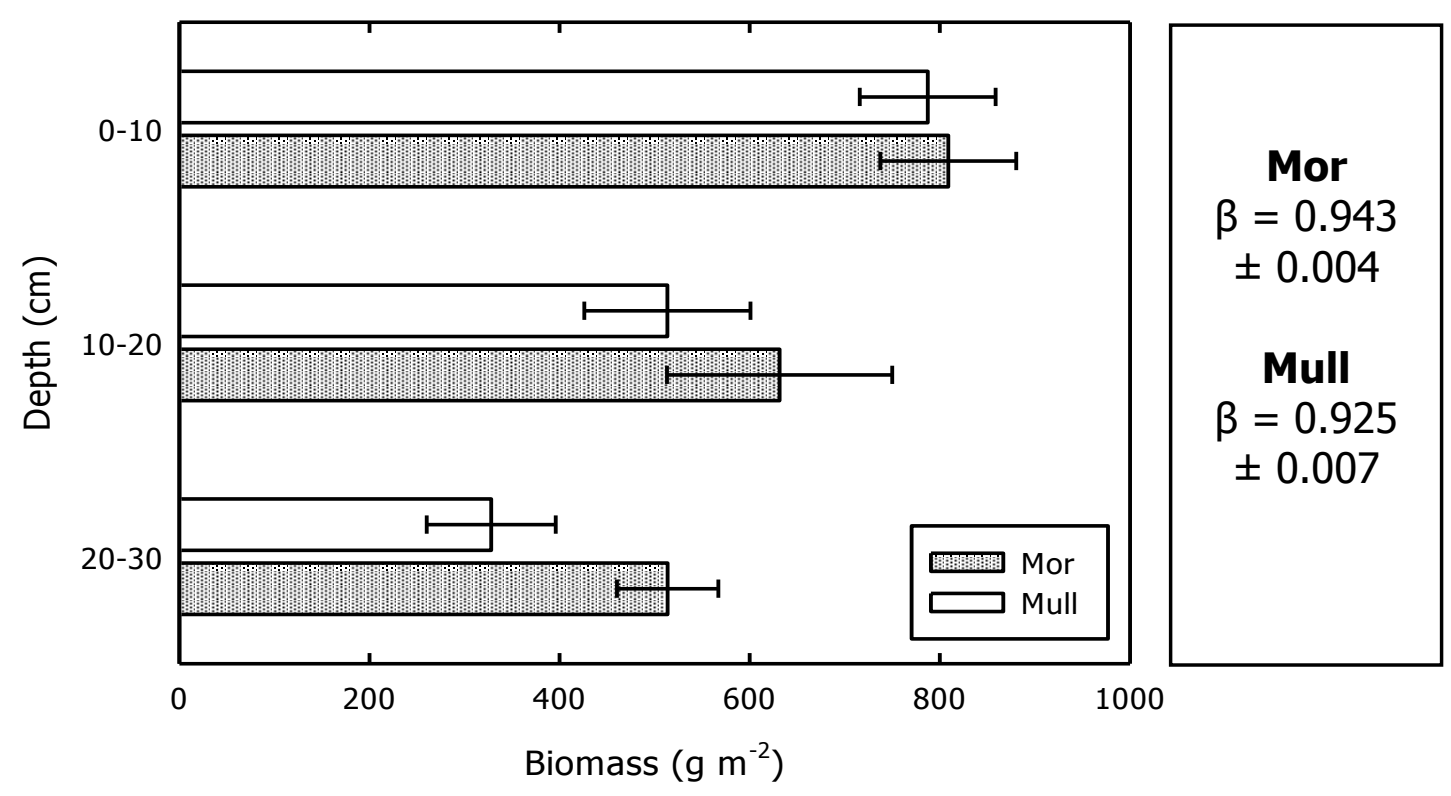


Table 1 Soil nitrogen concentrations and mineralisation rates in two contrasting forest types in the Blue Mountains of Jamaica assessed using $\mathrm{KCl}$ extractions of fresh soil and insitu deployment of $\mathrm{PRS}^{\mathrm{TM}}$ probes. Also included are results from two previous studies for comparative purposes. All values are mean \pm standard error.

\begin{tabular}{|c|c|c|c|}
\hline & Mor & Mull & \\
\hline \multicolumn{4}{|c|}{$\mathrm{KCl}$ extractions $\left(\mu \mathrm{g} \mathrm{g}^{-1}\right)-2008$} \\
\hline Ammonium & $0.79 \pm 0.31$ & $0.48 \pm 0.09$ & $t_{5}=0.98, p=0.37$ \\
\hline Nitrate & $0.28 \pm 0.25$ & $0.20 \pm 0.09$ & $t_{6}=0.29, p=0.78$ \\
\hline Nitrate: Ammonium & $0.19 \pm 0.13$ & $0.48 \pm 0.17$ & $t_{10}=1.37, p=0.20$ \\
\hline \multicolumn{4}{|c|}{$\mathrm{KCl}$ extractions $\left(\mu \mathrm{g} \mathrm{g}^{-1}\right)-2010$} \\
\hline Ammonium & $0.80 \pm 0.15$ & $0.39 \pm 0.05$ & $t_{8}=2.67 p=0.028$ \\
\hline Nitrate & $0.55 \pm 0.31$ & $1.50 \pm 0.56$ & $t_{8}=1.49 p=0.18$ \\
\hline Nitrate: Ammonium & $1.07 \pm 0.64$ & $4.22 \pm 1.55$ & $t_{8}=1.88 p=0.097$ \\
\hline \multicolumn{4}{|c|}{ PRSTM probes $\left(\mu \mathrm{g} 10 \mathrm{~cm}^{-2} 49\right.$ days $\left.^{-1}\right)$} \\
\hline Ammonium & $15.9 \pm 10.0$ & $12.6 \pm 5.6$ & $t_{6}=0.32, p=0.76$ \\
\hline Nitrate & $7.4 \pm 0.83$ & $162 \pm 49.0$ & $t_{4}=3.15, p=0.035$ \\
\hline Nitrate: Ammonium & $0.98 \pm 0.42$ & $26.9 \pm 12.0$ & $t_{4}=2.08, p=0.11$ \\
\hline \multicolumn{4}{|c|}{ Nitrogen mineralisation $\left(\mu \mathrm{g} \mathrm{g}^{-1} 10 \mathrm{~d}^{-1}\right)$} \\
\hline Mineralisation & $0.25 \pm 0.21$ & $1.34 \pm 0.53$ & $t_{5}=1.67, p=0.16$ \\
\hline Nitrification & $0.01 \pm 0.09$ & $1.52 \pm 0.35$ & $t_{5}=3.61, p=0.015$ \\
\hline \multicolumn{4}{|c|}{ Nitrogen mineralisation $\left(\mathrm{kg} \mathrm{ha}^{-1} 10 \mathrm{~d}^{-1}\right)^{+}$} \\
\hline Mineralisation & $0.025 \pm 0.021$ & $0.803 \pm 0.119$ & $\boldsymbol{x}$ \\
\hline Nitrification & $0.001 \pm 0.009$ & $0.912 \pm 0.078$ & $x$ \\
\hline \multicolumn{4}{|c|}{ Values from Tanner (1977) } \\
\hline Ammonium $\left(\mu \mathrm{g} \mathrm{g}^{-1}\right)$ & 364 & 239 & - \\
\hline Nitrate $\left(\mu g g^{-1}\right)$ & 31 & 17 & - \\
\hline Nitrate:Ammonium & 0.085 & 0.071 & - \\
\hline Mineralisation $\left(\mu \mathrm{g} \mathrm{g}^{-1} 40 \mathrm{~d}^{-1}\right)$ & 88 & 160 & - \\
\hline Nitrification $\left(\mu \mathrm{g} \mathrm{g}^{-1} 40 \mathrm{~d}^{-1}\right)$ & 100 & 136 & - \\
\hline \multicolumn{4}{|c|}{ Values from Hafkenscheid $(2000)^{*}$} \\
\hline Ammonium $\left(\mu g g^{-1}\right)$ & 471 & 235 & n.s. \\
\hline Nitrate $\left(\mathrm{mg} \mathrm{g}^{-1}\right)$ & 6.2 & 10.6 & n.s. \\
\hline Nitrate:Ammonium & 0.013 & 0.046 & - \\
\hline Mineralisation $\left(\mu \mathrm{g} \mathrm{g}^{-1} \mathrm{~d}^{-1}\right)$ & -0.33 & 8.0 & n.s. \\
\hline Nitrification $\left(\mu g g^{-1} d^{-1}\right)$ & 0.17 & 0.38 & n.s. \\
\hline
\end{tabular}

${ }^{+}$n.b. same data as above but converted to different units

* From 'moderately developed' mor ridge forest and 'poorly developed' mull ridge forest 
Table 2 Soil ammonium and nitrate $\delta^{15} \mathrm{~N}$ values (\%o) from $0-10 \mathrm{~cm}$ depth in two contrasting forest types in the Blue Mountains of Jamaica. Also included are bulk soil $\delta^{15} \mathrm{~N}$ values $(0-10 \mathrm{~cm})$ from Figure 3. All values are mean \pm standard error.

\begin{tabular}{|l|c|c|}
\hline & Mor & Mull \\
\hline Ammonium & $-5.50 \pm 1.27$ & $-0.26 \pm 1.51$ \\
\hline Nitrate & $-14.39 \pm 1.05$ & $-12.71 \pm 2.36$ \\
\hline Bulk soil & $-2.40 \pm 0.26$ & $0.66 \pm 0.41$ \\
\hline
\end{tabular}

